\title{
Governance Matters and Economic Growth: Beyond the Egyptian Revolution
}

\author{
Islam Abdelbary ${ }^{1,2}$ \\ ${ }^{1}$ The Arab Academy for Science and Technology (AAST), Alexandria, Egypt \\ ${ }^{2}$ Plymouth University, Plymouth, UK \\ Email: Islam.abdelbary@plymouth.ac.uk, I.abdelbary@live.com
}

How to cite this paper: Abdelbary, I. (2018) Governance Matters and Economic Growth: Beyond the Egyptian Revolution. Theoretical Economics Letters, 8, 741-754. https://doi.org/10.4236/tel.2018.84051

Received: February 13, 2018

Accepted: March 16, 2018

Published: March 19, 2018

Copyright $\odot 2018$ by author and Scientific Research Publishing Inc. This work is licensed under the Creative Commons Attribution International License (CC BY 4.0).

http://creativecommons.org/licenses/by/4.0/

\begin{abstract}
Following the Egyptian revolution in January 2011, the need for a new development approach has become essential. That is development with a human face. This study aims to contribute to the discussion on sustainable economic growth in Egypt by examining the interdependence of inclusive governance, economic and social inclusion, through empirically assessing the relationship between governance indicators and economic growth in Egypt. The study applied a vector error correction model (VECM) to assess the causal relationship between the two key variables, using Worldwide Governance Indicators (WGI) from the World Bank and economic indicators from Economic Intelligent Unit (EIU) database over the period 1996-2016. The results show that the Egyptian economy suffered during the study period from a significant decrease in the level of governance. The analysis indicated that most of the governance indicators have a causal relationship with economic growth except corruption control, while economic growth has a positive effect and contributes to the development of political stability and regulatory quality. The paper concludes that appropriate initiatives and efficient governance could play a significant role in influencing economic growth in Egypt. This is consistent with previous studies on the impact of institutions on economic growth and development. However, these results need further investigation to determine additional key variables that influence the growth of GDP in Egypt.
\end{abstract}

\section{Keywords}

Governance, Economic Growth, Egyptian Revolution, Arab Spring, Vector Error Correction Model (VECM)

\section{Introduction}

Egypt still suffers from numerous economic problems despite its development 
process starting several years back. In the 1990s and 2000s, the economic growth implications and attempts to reform, in addition to the emergence of a new development model was obvious [1]. Although implementing series of economic reforms with emphasis on stabilisation and achieving more than 7\% in economic growth, these reforms did not significantly improve upon the living standards of Egyptians owing to poor governance, weak institutional framework, inequity, corruption and an increasing gap between governmental policies and people needs and aspirations. That led to the eruption of the youth revolutions in the country; the focus shifted towards exploring alternative solutions and scope of development policy options to help redress the underlying causes that gave rise to widespread popular grievances and discontent. The slogan apparently encapsulated these claims: "Bread, freedom and social justice" - a motto of 2011 revolution that underlines the interdependence of inclusive governance, and economic and social inclusion [2].

Following the revolution, the need for a new development model has become essential, where issues of stability are not only addressed from a security aspect. It has been argued that a nation such as Egypt needs a new developmental approach that is capable of transforming the enormous potential and natural resources of the country into an inclusive growth base that respects human rights, reduces poverty, creates decent work opportunities and views social expenditure as a real investment in the future [3]. This would lead to long-term sustainable growth.

Over the last few years, economists have dedicated increasing attention to the impacts of political institutions and issues of governance in the process of economic growth. The burgeoning research on the topic has indicated a widespread consensus in that economic performance is not always warranted by economic features alone, but it is often formed by the political and institutional environment in which economic enterprises take place [4].

According to Globerman and Shapiro [5], empirical evidence from the development literature has argued that governance matters for improved economic development. Therefore, the study contributes to this discussion through explaining the trends of governance indicators in Egypt and examines the causal consequence between institutional structures and economic growth in Egypt using time series analysis for 21 years.

The rest of the paper is organised as follows: the second section is a brief overview of previous related studies, while Section 3 presents the methodology and model specification. Section 4 discusses the results of the analyses, with the last section concentrating on conclusions and policy implications.

\section{Review of Related Literature}

Governance has its roots in the word "govern" and is usually thought of as "government" though it transcends the latter owing to its complexity and as a universal force existing in all societies. Governance is used to manage human inter- 
action and activities with several realities of the term ranging from related notions such as state governance, corporate governance, local governance, global governance, etc. [6].

The United Nations Development Programme [7] defines governance as "the exercise of economic, political and administrative authority in the management of a country's affairs at all levels. It comprises the complex mechanisms, processes and institutions, through which citizens and groups articulate their interests, mediate their differences and exercise their legal rights and obligations". The World Bank through its Development Institute's Task Force on Governance views governance from both an analytic and operational framework [8]. Thus, governance is defined as "the traditions and institutions by which authority in a country is exercised for the common good". This includes the process of how those in authority are selected, monitored and replaced; the capacity of the government to effectively manage its resources and implement sound policies; and the respect of citizens and the state of institutions that govern economic and social interactions among them [8] [9].

There are numerous theories of governance and development stemming from various disciplines in the social sciences, as well as from interdisciplinary perspectives. Overall, there are three main economic schools of thought on the role of governance in development (with several sub-schools of thought within each school] [10]: 1) the "successful society"; 2) the governance for growth school, which has recently emerged as the "cautionary school of governance for growth"; and 3) the "social order" school.

The first school of thought centres around shaping the governance and development agenda with a focus on key features and characteristics of a "successful society". In other words, what key characteristics of governance in developed countries should be imitated, emulated or adapted by developing countries. The second school is informed by the interpretation of the dynamics of the relationship between governance and economic growth not only from increases in per capita income perspective but also enhanced governance is viewed to be at the heart of the development puzzle [11]. The third school was the brainchild of North [12] who divide the world into two parts, $85 \%$ of the world's population who have a social order that first seemed about ten millennia ago, and exists to this day in various forms or phases that are part of the "natural state" (which replaced the primitive or first social order). The remaining $15 \%$ of the global population, are characterised by the third social order, which first appeared in a few societies at the end of the eighteenth and beginning of the nineteenth centuries-the "open access" society.

However, the common feature in these three schools of thought is that institutions do matter. Yet, the differences in each theory also lie in the perspectives on, as well as the context and approach to, institutions, societies and the dynamics of development progress. The current research argues that these schools complement each other in highlighting the role of governance and institutions in development. Moreover, the three schools describe the new institutional econom- 
ics theory from strategies and operation levels. In other words, it presents the action plans for how societies transfer from basic level of resource allocation and employment to social embeddedness level in terms of the four levels of social analysis.

Empirically, numerous studies in the literature have assessed the role of institutions in economic development. The main conclusion that has emerged is that governance is positive and statistically significant determinant of economic growth [13] [14] [15] [16] [17]. Most of the empirical studies on the links between institutions and economic performance employ pure cross-sectional approaches, such as Knack and Keefer [18], and Grogan and Moers [19]. These studies proved that economic growth leads to better institutions due to the accumulation of human and social capital. For instance, Glaeser, La Porta et al. [20] point out "as a society grows richer, institutional opportunities improve." As people become richer, they demand more from their public institutions-better bureaucratic qualities, regulations, more security, and law and order. Barro [21] has found the same result from a political science perspective that democratisation follows income. As countries become more prosperous, on average, they also become more democratic and grant more political freedoms to their citizens.

Although the relationship between governance and economic growth is well documented, the positive associations are insufficient for establishing the direction of causality between the two variables because the cross-section nature of the technique employed in the literature does not allow different countries to exhibit different patterns of causality [22]. Moreover, the results of cross-section analysis can quickly change with addition or reduction in the number of countries.

The first systematic study of causality between institutions and growth using time series analysis was conducted by Chong and Calderon [23], utilising the BERI and ICRG institutions datasets. Their empirical findings demonstrate that the poorer the country and the longer the wait for institutional development, the higher the influence of institutions on economic growth. They also demonstrate the existence of two-way causality; not only do institutions Granger cause economic growth, but economic growth also contributes to institutional quality improvement.

Furthermore, some studies have used panel data analysis. For example, Lee and Kim [24] concluded that there is bi-directional causation between institutions, governance and economic growth, using a sample of 63 countries for the period 1965-2002. They also divided the sample countries into two groups, namely higher income countries (high and upper middle income) and lower income countries (low and lower middle income). Their findings indicate that institutions are statistically significant determinants of growth in both groups, but the role of institutions diminishes in high-income countries, as more variables are added to the model specification. These results were consistent with another 
panel data analysis by Law et al. [22] who examines the causal effect between institutions and economic development using the panel Granger causality test. The findings also suggest that causality patterns between institutions and economic performance vary at different stages of income level. Better institutional quality fosters economic development in higher income countries, whereas economic development tends to enhance institutional quality in lower income countries.

Following these studies, this paper examines factors that boost economic growth in the Arab spring countries through verifying the nature of the causal relationship between governance and economic growth in Egypt. This is important given the limited studies in the Arab world and the recent Arab Spring, which was underpinned by the poor governance in those countries.

\section{Methodology}

\subsection{Estimation Approach}

The study applied a combination of analytical and econometric methods to assess the indicators of Worldwide Governance Indicators (WGI) from World Bank and economic indicators from Intelligent Economic Unit (EIU) database over the period 1996 to 2016. The analyses also examine the trends and directions of the indicators, as well as correlations between them, and determine causation relationship between governance and economic growth.

A vector error correction model (VECM) is applied to assess the causal relationship between governance and economic growth following the study by Law et al. [22]. The approach follows three steps. The first step is conducting a unit root test on each variable to determine the order of integration using the Augmented Dickey-Fuller (ADF) and Phillips-Perron (PP) tests. If all variables are integrated of the same order, the second step is to estimate a co-integrating equation, and test whether the residual of the model is stationary. The purpose of this step is to implement an Engel Granger approach for co-integration to test whether the data have a long run relationship or not. These tests make sure that either all-time series variables in the model are stationary or they are co-integrated, If this is the case, then the model defines a long-run equilibrium relationship among the co-integrated variables [22] [23] [24] [25]. Following the confirmation of co-integration between the variables, the causal relationship between governance indicators and growth (GDP) is determined through the analysis of Granger causality (Multivariate Granger Causality).

\subsection{Data sources and Variables}

Governance indicators measure the state of governance in a country and are often narrowed down to specific characteristics such as levels of corruption, human rights, civil and political liberties. Until recently, obtaining quantitative measures for any characteristics of governance was impossible, and not a trivial matter as several of these characteristics are, in principle, multidimensional [6].

The World Governance Indicators dataset developed by World Bank re- 
searchers is the most comprehensive dataset on governance because it is an aggregation of a wide variety of data on 250 measures from 25 separate data sources including the Freedom House's civil liberties and political rights indices, and the ICRG [9]. The governance dataset captures three dimensions of governance: firstly, the process by which governments are selected, monitored and replaced; secondly, the capacity of the government to effectively formulate and implement sound policies; and lastly the respect for citizens and the quality of institutions that govern economic and social interactions among them. The dataset measures six indicators (two each) corresponding to these dimensions by reducing the measures through an unobserved components model, resulting in a total of six dimensions of governance, and is available for the periods 1996 to 2016 [26] [27]. The first aspect reflects Voice and Accountability [VA], Political Stability and Absence of Violence/Terrorism (PV), while the second focus on Government Effectiveness (GE) and Regulatory Quality (RQ), and the third, Rule of Law (RL) and Control of Corruption (CC).

The aggregated WGI are measured in two ways: in the standard normal units of the governance indicator, ranging from -2.5 to 2.5 . These six dimensions of governance should not, however, be thought of as being somehow independent of each other. One might reasonably think for example that better accountability mechanisms lead to less corruption, or that a more effective government can provide a better regulatory environment, or that respect for the rule of law leads to fairer processes for selecting and replacing governments and less abuse of public office for private gain [27]. Table 1 presents descriptive statistics of all governance indicators based on standard normal units, in addition to the dependent variable (GDP growth) in Egypt over 1996-2016.

\section{Results and Discussion}

\subsection{The Governance Indicators Status in Egypt}

Based on Appendix 1 and figures in Appendix 3, Table 2 summarises the score

Table 1. Descriptive statistics of governance indicators and GDP growth.

\begin{tabular}{cccccccc}
\hline & CC & VA & RL & RQ & PS & GE & GDP Growth \\
\hline Mean & -0.59 & -1.05 & -0.20 & -0.42 & -0.76 & -0.46 & 4.40 \\
Median & -0.62 & -1.08 & -0.11 & -0.41 & -0.63 & -0.39 & 4.37 \\
Maximum & -0.41 & -0.77 & 0.02 & -0.05 & 0.05 & -0.22 & 7.16 \\
Minimum & -0.78 & -1.23 & -0.66 & -0.92 & -1.64 & -0.88 & 1.78 \\
Std. Dev. & 0.11 & 0.14 & 0.24 & 0.23 & 0.56 & 0.21 & 1.62 \\
Skewness & -0.10 & 0.37 & -0.81 & -0.58 & -0.27 & -0.77 & 0.12 \\
Kurtosis & 2.11 & 1.77 & 2.15 & 2.71 & 1.86 & 2.31 & 2.13 \\
Sum & -12.42 & -22.00 & -4.19 & -8.92 & -15.89 & -9.63 & 92.34 \\
Observations & 21 & 21 & 21 & 21 & 21 & 21 & 21 \\
\hline
\end{tabular}

Source: Author. 
Table 2. Summary of governance indicators in Egypt by score (1996-2016).

\begin{tabular}{cccccc}
\hline Governance Indicators & 1996 & $\mathbf{2 0 0 0}$ & $\mathbf{2 0 0 5}$ & $\mathbf{2 0 1 0}$ & 2016 \\
\hline Voice and Accountability & -0.88 & -0.79 & -0.95 & -1.15 & -1.23 \\
Political Stability * & -0.58 & -0.01 & -0.65 & -0.91 & -1.42 \\
Government Effectiveness* & -0.21 & -0.16 & -0.39 & -0.38 & -0.66 \\
Regulatory Quality & 0.01 & -0.35 & -0.41 & -0.16 & -0.92 \\
$\quad$ Rule of Law* & 0.05 & -0.01 & 0.03 & -0.12 & -0.41 \\
Control of Corruption & -0.07 & -0.39 & -0.52 & -0.55 & -0.63 \\
\hline
\end{tabular}

Source: World Bank (2017). ${ }^{*}$ The variable is significant to change as a function of time $(P$-Value $<0.05) \mathrm{VA}$ $=0.011, \mathrm{PA}=0.002, \mathrm{GE}=0.002, \mathrm{RL}=0.001, \mathrm{CC}=0.000$, while $\mathrm{RQ}$ is insignificant $=0.57$.

of the six governance indicators for Egypt over 1996 and 2016. Voice and Accountability started with a score of -0.88 in 1996 and continued to improve until it reached the highest score -0.74 in 2012 after the only free presidential election in the country but fell again ending with a score of -1.23 in 2016. Political Stability and Absence of Violence improved from -0.58 to -0.01 in 2000 and then started deteriorating until it reached -1.42 in 2016. Government Effectiveness started with a score of -0.21 in 1996 and improved slightly to -0.16 in 2000, deteriorated up to 2005 , remained steady until 2010 with a score of -0.38 , but deteriorating further reaching -0.66 in 2016. Regulatory Quality started with 0.01 in 1996 then decreased until it reached -0.41 in 2005, after that it showed a dramatic fall to -0.92 in 2016. Similarly, Rule of Law fluctuated between 0.05 and -0.01 between 1996 and 2000, improved between 2001 and 2005, but decrease after 2010 until it reached -0.41 in 2016. Lastly, Control of Corruption started with -0.07 in 1996 and fluctuated within the same negative index reaching -0.63 in 2016.

These indicators confirm that although economic underdevelopment was one of the causes of the Egyptian uprising in 2011, state corruption and mismanagement were the real reasons behind this underdevelopment. For instance, in 1990's when Egypt attempted to implement the structural reform program to liberalise its economy, the privatisation processes did not create a sustainable economic growth that could serve as the new beginning of legitimacy for the regime. Alternatively, poorly designed and inadequately implemented market reforms led to increased incidence of corruption and socioeconomic inequality, including creating a new class of super-wealthy entrepreneurs [28]. Those political elites usually tend to prefer personal interest above the common good through accumulating financial wealth by monopolistic structures, which have become a significant weapon to hinder or distort reforms.

Remarkably, no changes were noticed in relation to the trend of all indicators after 2011, except a slight improvement in the rule of law and government effectiveness indicators, although to a much lesser extent than before 2011. However, six years since the revolution in 2011, the route to the modern democratic state in Egypt is filled with obstacles. The civil uprising could not resolve the problem 
related to alleged corrupt institutions and aspects of the former regime.

The root of this failure is strongly related to Mubarak's era (1981-2011), during which Egyptians were deprived of their basic political rights. The emergency law had been imposed all the time, associated with an absence of pluralism, political freedom and freedom of expression and protest [29]. This situation led to the lack of political practice and discouraged any chance for the opposition to play a real role in the political life or to develop political leaders equipped with political skills, which reflected directly on political life after the revolution. Besides, the uprising has not dismantled the structures of the old regime entirely [30], only the leadership of the former administration was displaced; while the rest of the regime has stayed in their positions with all responsibilities and influences. Thus, any step toward reform and accountability would be a real threat to their interests, with the risk of being imprisoned, due to their actions during Mubarak's era. Therefore, they have been doing their best to deactivate the transition in Egypt [31].

\subsection{The Relationship between Governance Indicators and Economic Growth in Egypt}

Table 3 shows that most of the governance indicators were significantly associated with economic growth with varying power of association; only voice and accountability, and control of corruption have a negative correlation with economic growth. However, these correlations between indicators of governance and economic growth do not demonstrate that any of them causes the other, and therefore does not infer the existence of a causal relationship. Thus, this analysis is verified using the Granger causality test.

As mentioned earlier, ADF and PP tests are carried out to assess if the data is integrated of the same order. The following table shows the results of the ADF and PP tests. Based on the results all variables are non-stationary at the level but are stationary at $5 \%$ level of significance in the first difference. The exceptions are for GE and VA, which according to the results of PP in Table 4 are significant at 10\% level. This means that all the variables are integrated of the same order.

Granger Causality is carried out to test the causal relationships between governance indicators and growth GDP (see Appendix 2). The results as summarised in Table 5 suggest that the null hypothesis is rejected for all variables except for CC, which means there is a causal relationship between those variables and GDP growth. In addition, growth (GDP) has bi-directional causality with PS and RQ.

Table 3. Matrix of correlation coefficients between governance indicators according to the units of measurement and GDP growth in Egypt during the period (1996-2016).

\begin{tabular}{ccccccc}
\hline & VA & PV & GE & RQ & RL & CC \\
\hline GDP Growth & -0.150 & $0.488^{*}$ & $0.474^{*}$ & $0.437^{*}$ & $0.358^{*}$ & -0.320 \\
\hline
\end{tabular}

Note: ${ }^{\star}$ Denote significant at $5 \%$ level. 
Table 4. ADF and PP Test results.

\begin{tabular}{cccccc}
\hline & & \multicolumn{2}{c}{ ADF } & PP \\
\cline { 3 - 6 } & & At Level & First Difference & At Level & First Difference \\
\hline \multirow{2}{*}{ GDPG } & t-Statistic & -2.685 & -4.061 & -1.807 & -4.0623 \\
& Prob & 0.1008 & 0.0304 & 0.3634 & 0.0304 \\
CC & t-Statistic & -2.1767 & -4.4572 & -2.6052 & -9.0891 \\
& Prob & 0.2209 & 0.0157 & 0.1123 & 0.0000 \\
GE & t-Statistic & -3.3221 & -2.0968 & -1.1638 & -1.9037 \\
& Prob & 0.1004 & 0.0384 & 0.8831 & 0.0566 \\
PV & t-Statistic & -3.1889 & -2.6840 & -2.2523 & -2.6579 \\
& Prob & 0.1262 & 0.0110 & 0.4329 & 0.0117 \\
\multirow{2}{*}{ RL } & t-Statistic & -2.5010 & -3.4913 & -0.1931 & -2.6038 \\
& Prob & 0.3227 & 0.0251 & 0.9214 & 0.0131 \\
\multirow{2}{*}{ RQ } & t-Statistic & -2.1711 & -2.4012 & -2.3857 & -2.3177 \\
& Prob & 0.2231 & 0.0203 & 0.1605 & 0.0242 \\
VA & t-Statistic & -1.6505 & -2.0663 & -1.6509 & -1.9058 \\
& Prob & 0.4356 & 0.0408 & 0.4354 & 0.0564 \\
\hline
\end{tabular}

Source: Author using EViews 8 (see also Appendix 1).

Table 5. Summary results of causality patterns between economic growth and governance indicators.

\begin{tabular}{lllllll} 
& VA & PS & GE & RQ & RL & CC \\
\hline GGDP & & & &
\end{tabular}

Notes: $\mathrm{X} \rightarrow \mathrm{Y}$ indicates $\mathrm{X}$ Granger causes $\mathrm{Y} . \mathrm{X} \leftrightarrow \mathrm{Y}$ implies that $\mathrm{X}$ and $\mathrm{Y}$ Granger cause one another or a feedback relationship. $\mathrm{X} \neq \mathrm{Y}$ indicates $\mathrm{X}$ does not cause $\mathrm{Y}$. Source: Summary of Appendix 2.

As the GDP per capita increases, the wealth per individual also grows. This will improve the citizen's access to financial and other resources to cover the essentials of life such as education and health, and help to enhance their standard of living. It would also create more political awareness and increase the number of participants in governmental elections, in addition to higher demand for more rights and freedom. These issues would not get the needed attention if people can barely cover the minimum standard of living.

\section{Conclusion and Policy Implications}

This paper has empirically tested how the quality of governance explains economic growth in Egypt over the period 1996 and 2016. It has provided some justification for linking development problems to a crisis of governance and the current emphasis on strengthening the performance of governance in combating poverty. The Egyptian economy has suffered during the study period from a significant decrease in the level of governance, which has appeared in all the gov- 
ernance indicator scores. In addition, the analysis of the direction of indicators has shown a further deterioration of these indicators over time. This has negatively affected the rate of economic growth. Thus, the Egyptian economy has been under considerable pressure in the wake of its revolution.

Regarding the correlation relationship between governance and economic growth in Egypt, most of the governance indicators were associated positively with indices of economic growth except control of corruption and voice and accountability. The causality relationship tested has shown that most governance indicators cause economic growth, except corruption control variable, while economic growth has a positive effect and contributed to development based on political stability and regulatory quality indicators. These results are consistent with those of Chong and Calderon [23] and Law et al. [22] who examine the same causal effect between institutions and economic growth using the panel Granger causality test. They had the same conclusion that better institutional quality fosters economic growth in higher income countries, whereas economic development tends to enhance institutional quality in lower-income countries, which is the case of Egypt.

In conclusion, the study confirms that suitable initiatives and efficient governance could play a significant role in influencing economic growth in Egypt, which is consistent with previous studies on the impact of institutions on economic growth and development. That governance leads to enhanced economic activities, and improved economic performance also promotes institutional quality. The study confirmed a positive relationship between the level of institutions and economic growth in Egypt. A higher level of governance is associated with a higher level of economic growth. Similarly, a higher level of political rights and civil liberties stimulates investment and economic growth. However, these results need further investigation to determine why corruption control variable does not cause growth and what other variables cause GDP growth in Egypt.

\section{Acknowledgements}

The author would like to thank his PhD supervisor Associate Professor James Benhin for his unwavering support and assistance. The author also wishes to thank Dr Sherine Shawky from the Social Research Center at American University in Cairo for her valuable suggestions and discussions, and the anonymous reviewers for their very constructive comments on the paper.

\section{References}

[1] Bibi, S. and Nabli, M. (2010) Equity and Inequality in the Arab Region. Policy Research Report 33.

[2] UNDP (2011) Arab Development Challenges: Toward the Developmental State in the Arab Region. United Nations Development Programme, Regional Centre for Arab States, Cairo.

[3] Malik, A. and Awadallah, B. (2013) The Economics of the Arab Spring. World De- 
velopment, 45, 296-313. https://doi.org/10.1016/j.worlddev.2012.12.015

[4] Kaufmann, D. and Kraay, A. (2008) Governance Indicators: Where Are We, Where Should We Be Going? The World Bank Research Observer, 23, 1-30. https://doi.org/10.1093/wbro/lkm012

[5] Globerman, S. and Shapiro, D. (2002) Global Foreign Direct Investment Flows: The Role of Governance Infrastructure. World Development, 30, 1899-1919. https://doi.org/10.1016/S0305-750X(02)00110-9

[6] Akpan, G.E. and Effiong, E.L. (2012) Governance and Development Performance: A Cross-Country Analysis of Sub-Saharan Africa. Journal of Economics and Sustainable Development, 3, 54-65.

http://pakacademicsearch.com/pdf-files/ech/520/54-65\%20Vol\%203,\%20No\%2014 $\% 20(2012) . p d f$

[7] UNDP (1997) Governance for Sustainable Human Development-A UNDP Policy Document. UNDP, New York.

[8] Resnick, D. and Birner, R. (2006) Does Good Governance Contribute to Pro-Poor Growth? A Review of the Evidence from Cross-Country Studies. International Food Policy Research Institute (IFPRI), Washington, DC.

[9] Kaufmann, D., Kraay, A. and Zoido-Lobatón, P. (1999) Aggregating Governance Indicators. World Bank Publications, Washington, DC.

[10] Chibba, M. (2009) Governance and Development: The Current Role of Theory, Policy and Practice. World Economics, 10, 79-108.

[11] Rodrik, D. (2008) Thinking about Governance. Governance, Growth and Development Decision-Making. World Bank, Washington DC.

[12] North, D.C., Wallis, J.J. and Weingast, B.R. (2009) Violence and Social Orders: A Conceptual Framework for Interpreting Recorded Human History. Cambridge University Press, Cambridge. https://doi.org/10.1017/CBO9780511575839

[13] Aron, J. (2000) Growth and Institutions: A Review of the Evidence. World Bank Research Observer, 15, 99-135. https://doi.org/10.1093/wbro/15.1.99

[14] Gagliardi, F. (2008) Institutions and Economic Change: A Critical Survey of the New Institutional Approaches and Empirical Evidence. The Journal of Socio-Economics, 37, 416-443. https://doi.org/10.1016/j.socec.2007.03.001

[15] OECD (2002) Governance for Sustainable Development. OECD Publishing, Paris.

[16] Oman, C. and Arndt, C. (2006) Uses and Abuses of Governance Indicators. OECD Publishing, Paris. https://doi.org/10.1787/244762742121

[17] Pinar, M. (2015) Measuring World Governance: Revisiting the Institutions Hypothesis. Empirical Economics, 48, 747-778. https://doi.org/10.1007/s00181-013-0796-0

[18] Knack, S. and Keefer, P. (1995) Institutions and Economic Performance: Cross-Country Tests Using Alternative Institutional Measures. Economics \& Politics, 7, 207-227. https://doi.org/10.1111/j.1468-0343.1995.tb00111.x

[19] Grogan, L. and Moers, L. (2001) Growth Empirics with Institutional Measures for Transition Countries. Economic Systems, 25, 323-344. https://doi.org/10.1016/S0939-3625(01)00030-9

[20] Glaeser, E.L., La Porta, R., Lopez-de-Silanes, F. and Shleifer, A. (2004) Do Institutions Cause Growth? Journal of Economic Growth, 9, 271-303. https://doi.org/10.1023/B:JOEG.0000038933.16398.ed

[21] Barro, R.J. (1996) Democracy and Growth. Journal of Economic Growth, 1, 1-27. https://doi.org/10.1007/BF00163340 
[22] Law, S.H., Lim, T.C. and Ismail, N.W. (2013) Institutions and Economic Development: A Granger Causality Analysis of Panel Data Evidence. Economic Systems, 37, 610-624. https://doi.org/10.1016/j.ecosys.2013.05.005

[23] Chong, A. and Calderon, C. (2000) Causality and Feedback between Institutional Measures and Economic Growth. Economics \& Politics, 12, 69-81. https://doi.org/10.1111/1468-0343.00069

[24] Lee, K. and Kim, B.-Y. (2009) Both Institutions and Policies Matter but Differently for Different Income Groups of Countries: Determinants of Long-Run Economic Growth Revisited. World Development, 37, 533-549. https://doi.org/10.1016/j.worlddev.2008.07.004

[25] Christopoulos, D.K. and Tsionas, E.G. (2004) Financial Development and Economic Growth: Evidence from Panel Unit Root and Cointegration Tests. Journal of Development Economics, 73, 55-74.

[26] Huynh, K.P. and Jacho-Chávez, D.T. (2009) Growth and Governance: A Nonparametric Analysis. Journal of Comparative Economics, 37, 121-143. https://doi.org/10.1016/j.jce.2008.08.003

[27] Kaufmann, D., Kraay, A. and Mastruzzi, M. (2010) The Worldwide Governance Indicators: Methodology and Analytical Issues. World Bank Policy Research Working Paper. World Bank, Washington, DC.

[28] Paolo Verme, B.M., Sherine Al-Shawarby, Sahar El Tawila, May Gadallah and Enas Ali A.El-Majeed. (2014) Inside Inequality in the Arab Republic of Egypt: Facts and Perceptions across People, Time, and Space. World Bank, Washington, DC, 152 p.

[29] Boening, A.B. (2014) The Arab Spring: Re-Balancing the Greater Euro-Mediterranean? Springer, Berlin.

[30] Atawna, A.A.M. and Othman M.R. (2015) Obstacle Faced the Democratic Transition in Egypt in Muhammad Mursi Era. Procedia-Social and Behavioral Sciences, 172, 540-547. https://doi.org/10.1016/j.sbspro.2015.01.400

[31] Phillips, D.L. (2011) From Bullets to Ballots: Violent Muslim Movements in Transition. Transaction Publishers, Piscataway, NJ. 


\section{Appendices}

Appendix 1: Governance Indicators by Score, GDP Growth and GDP per Head in Egypt from 1996 to 2016

\begin{tabular}{ccccccccc}
\hline & VA & PS & GE & RQ & RL & CC & $\begin{array}{c}\text { Growth } \\
\text { GDP } \%\end{array}$ & $\begin{array}{c}\text { GDP } \\
\text { per capita* }\end{array}$ \\
\hline 1996 & -0.76 & -0.58 & -0.21 & 0.01 & 0.05 & -0.07 & 4.99 & 1711 \\
$\mathbf{1 9 9 7}$ & -0.79 & -0.32 & -0.19 & -0.16 & 0.01 & -0.16 & 5.49 & 1772 \\
$\mathbf{1 9 9 8}$ & -0.82 & -0.06 & -0.17 & -0.34 & -0.03 & -0.25 & 4.04 & 1810 \\
$\mathbf{1 9 9 9}$ & -0.80 & -0.04 & -0.16 & -0.34 & -0.02 & -0.32 & 6.11 & 1886 \\
$\mathbf{2 0 0 0}$ & -0.79 & -0.01 & -0.16 & -0.35 & -0.01 & -0.39 & 5.37 & 1951 \\
$\mathbf{2 0 0 1}$ & -0.94 & -0.23 & -0.28 & -0.42 & 0.02 & -0.34 & 3.54 & 1982 \\
$\mathbf{2 0 0 2}$ & -1.08 & -0.46 & -0.40 & -0.50 & 0.05 & -0.29 & 2.37 & 1991 \\
$\mathbf{2 0 0 3}$ & -1.08 & -0.66 & -0.30 & -0.62 & 0.06 & -0.47 & 3.19 & 2016 \\
$\mathbf{2 0 0 4}$ & -0.95 & -0.78 & -0.23 & -0.49 & 0.09 & -0.54 & 4.09 & 2059 \\
$\mathbf{2 0 0 5}$ & -0.95 & -0.65 & -0.39 & -0.41 & 0.03 & -0.52 & 4.48 & 2112 \\
$\mathbf{2 0 0 6}$ & -1.16 & -0.87 & -0.48 & -0.43 & -0.20 & -0.66 & 6.85 & 2217 \\
$\mathbf{2 0 0 7}$ & -1.12 & -0.59 & -0.38 & -0.28 & -0.18 & -0.67 & 7.09 & 2333 \\
$\mathbf{2 0 0 8}$ & -1.18 & -0.52 & -0.35 & -0.18 & -0.09 & -0.71 & 7.16 & 2457 \\
2009 & -1.12 & -0.62 & -0.27 & -0.19 & -0.06 & -0.42 & 4.67 & 2524 \\
$\mathbf{2 0 1 0}$ & -1.15 & -0.91 & -0.38 & -0.16 & -0.12 & -0.55 & 5.15 & 2602 \\
$\mathbf{2 0 1 1}$ & -1.11 & -1.45 & -0.55 & -0.33 & -0.39 & -0.65 & 1.78 & 2594 \\
$\mathbf{2 0 1 2}$ & -0.74 & -1.48 & -0.77 & -0.49 & -0.45 & -0.57 & 2.22 & 2593 \\
$\mathbf{2 0 1 3}$ & -1.05 & -1.64 & -0.88 & -0.64 & -0.63 & -0.63 & 2.19 & 2591 \\
$\mathbf{2 0 1 4}$ & -1.18 & -1.63 & -0.82 & -0.76 & -0.66 & -0.62 & 2.92 & 2608 \\
$\mathbf{2 0 1 5}$ & -1.18 & -1.50 & -0.75 & -0.84 & -0.59 & -0.64 & 4.37 & 2665 \\
$\mathbf{2 0 1 6}$ & -1.23 & -1.42 & -0.66 & -0.92 & -0.41 & -0.63 & 4.30 & 2724 \\
\hline
\end{tabular}

*constant 2010 US\$. Source: World Bank, (2017).

Appendix 2. Granger Causality Test Results on Error Correction Models (ECM)

\begin{tabular}{cccccccc}
\hline & GGDP & VA & PS & RQ & RL & CC & GE \\
\hline GGDP & & $67.84078^{*}$ & $90.20456^{*}$ & $39.88855^{*}$ & 1.525802 & $3.615723^{*}$ & $4926.670^{*}$ \\
VA & 0.915232 & & $179.6486^{*}$ & $8.763164^{*}$ & $8.646033^{*}$ & $10.66131^{*}$ & $1144.109^{*}$ \\
PS & $6.278304^{*}$ & $35.72095^{*}$ & & $12.78283^{*}$ & 3.701850 & $5.785389^{*}$ & $1742.272^{*}$ \\
RQ & 0.107445 & $51.11298^{*}$ & $34.68455^{*}$ & & 0.648681 & $7.130762^{\star}$ & $4518.392^{*}$ \\
RL & 4.558865 & $31.77217^{*}$ & $13.15558^{*}$ & $8.614027^{*}$ & & $21.14195^{*}$ & $3107.981^{*}$ \\
GE & 1.125043 & $69.48050^{*}$ & $194.6473^{*}$ & $23.43524^{*}$ & $8.879952^{*}$ & $6.066234^{*}$ & \\
CC & 3.546236 & $62.33500^{*}$ & $96.35796^{*}$ & $33.71224^{*}$ & 2.674971 & & $1757.801^{*}$ \\
\hline
\end{tabular}

Note: Values represent Chi-sq statistics and ${ }^{\star}$ denote significance at 5\% level. Source: Author using EViews 8. 
Appendix 3: Trend of Governance Indicators in Egypt (1996-2016)

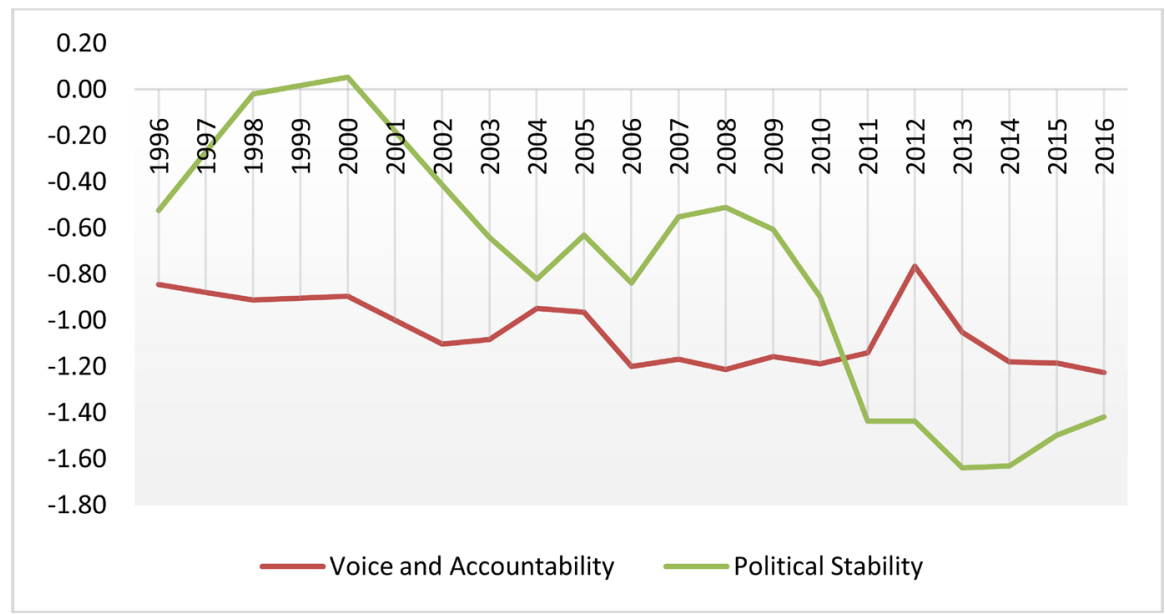

(a) Voice and Accountability (VA) \& Political Stability and Absence of Violence/Terrorism (PV).

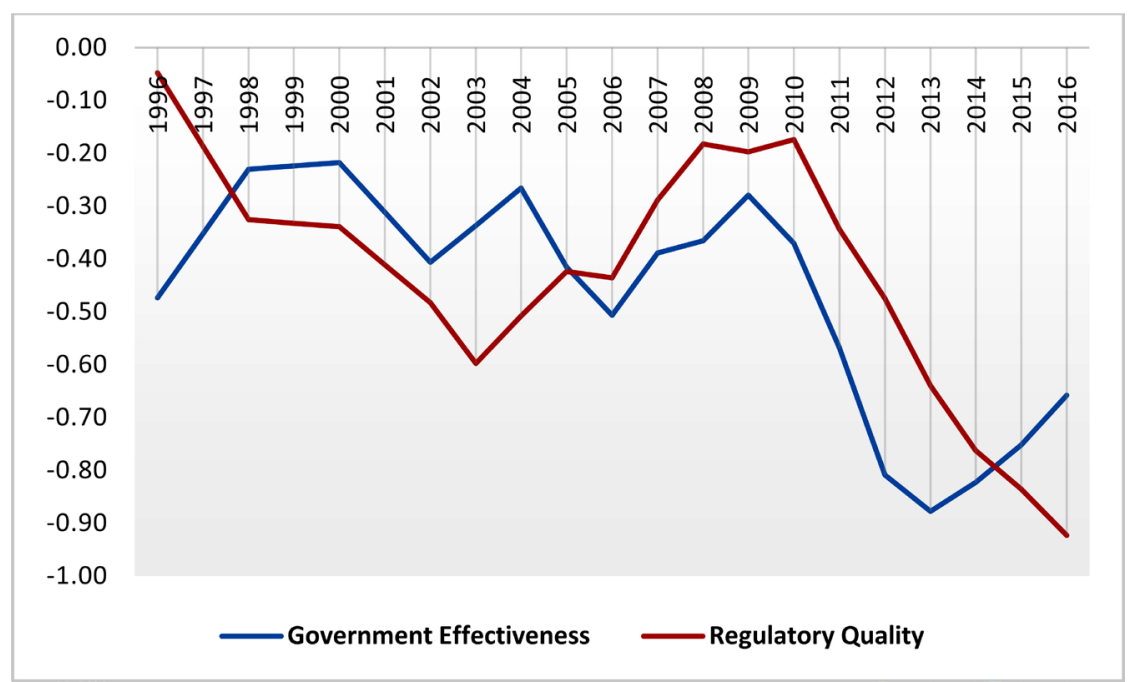

(b) Government Effectiveness (GE) \& Regulatory Quality (RQ).

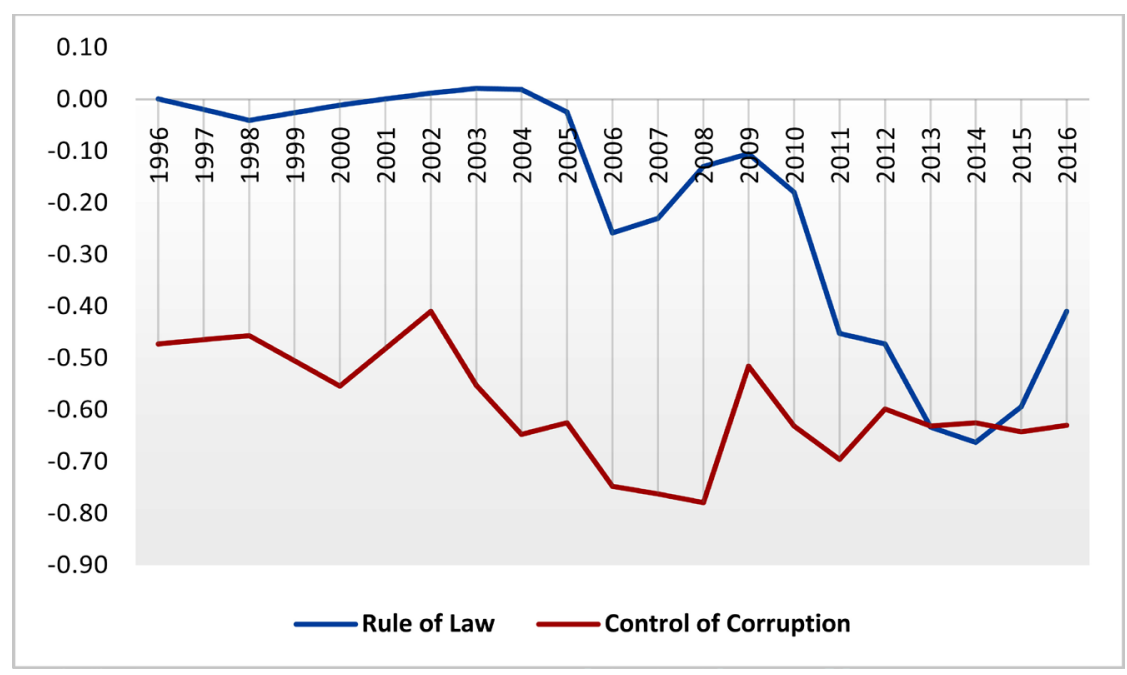

(c) Rule of Law (RL) \& Control of Corruption (CC). 